\title{
The Western Boundary Undercurrent as a Turbidity Maximum Over the Puerto Rico Trench
}

\author{
Brian E. Tucholke and Stephen Eittreim \\ Lamont-Doherty Geological Observatory, Palisades, New York 10964
}

\begin{abstract}
Nephelometer measurements in the Puerto Rico trench record a midwater light scattering maximum at the depth of the near-bottom nepheloid layer found in the deep Atlantic basin to the northwest. This midwater maximum is best developed near the south slope of the trench and is interpreted as a southeasterly continuation of the western boundary undercurrent, which has been documented along the continental rise of eastern North America. The eastward-advecting core of the flow overrides clearer colder antarctic bottom water that enters the trench from the east. A near-bottom nepheloid layer, best developed in the eastern part of the trench, appears to be associated with the westward-flowing antarctic bottom current.
\end{abstract}

The distribution of suspended sediment in the deep water of the western North Atlantic Ocean has been extensively studied by measurement of light scattering with deep-sea nephelometers [Ewing and Thorndike, 1965; Eittreim et al., 1969; Eittreim and Ewing, 1972]. These studies indicate that a nearbottom nepheloid layer persists over most of the basin and is particularly intense along the western margin, where the southward-flowing western boundary undercurrent is active.

The western boundary undercurrent is well documented along the continental rise of eastern North America [ $S$ wallow and Worthington, 1961; Volkmann, 1962; Heezen et al., 1966; Amos et al.. 1971]. It has been traced southward around the Caicos and Greater Antilles outer ridges [Tucholke et al., 1973], and the suggestion has been made that it flows southward just east of the Lesser Antilles [McCoy, 1969]. Between the Greater Antilles outer ridge and Navidad bank a sill at about 5200-m depth (here called Navidad sill) separates the sea floor of the southwestern North American basin from the depths (about $8390 \mathrm{~m}$ ) of the western Puerto Rico trench (Figure 1). Tucholke et al. [1973] suggested that part of the western boundary undercurrent may flow south across this sill and then east along the south slope of the Puerto Rico trench, but aside from the inclined isotherms along the south slope [Fuglister, 1960] there is little oceanographic evidence for the current. In this report we use the nepheloid layer associated with the western boundary undercurrent as a tracer of the current system over the Puerto Rico trench. The area investigated includes the main trench north of the Antilles island arc and the southerly topographic extension of the trench to about $13^{\circ} \mathrm{N}$ latitude east of the Lesser Antilles.

\section{Methods}

The Lamont nephelometer records vertical profiles of forward scattering of white light on a continuous film strip. The nephelometer, data acquisition, and data reduction are fully described for the early instruments in Thorndike and Ewing [1967] and for the more recent instruments in Eittreim and Ewing [1974] and Thorndike [1974]. Data are depicted in light scattering versus depth plots, where light scattering is expressed as the log of the ratio of intensity (film exposure $E$ ) of scattering at a point in the water column to the intensity from a direct attenuated light beam $\left(E_{D}\right)$. Four profiles discussed here (Conrad cruise 10, Vema cruises 24 and 25) had no sensitometer control to establish the contrast characteristics of the

Copyright $(\odot 1974$ by the American Geophysical Union. film, and for these profiles scattering is expressed in units of film optical density normalized to equal zero at the clearest water of the water column.

Unfortunately, no detailed program of light scattering measurements has been conducted in the Puerto Rico trench, and so the station distribution is random, but it covers most of the physiographic subprovinces in the trench (Figure 1). Seven of the thirteen stations utilized (C16-24 to $\mathrm{C} 16-31)$ were taken in September of 1972 over a period of 2 weeks, and they provide a relatively synoptic picture of light scattering in the trench. The other profiles were taken in various seasons between 1965 and 1973; features common to these and the Conrad 16 profiles suggest long-term stability of the observed light scattering patterns.

\section{Presentation of Data}

The nephelometer profiles studied can be categorized into three general classes. The first class is typical of most nephelometer profiles in the western boundary undercurrent and has a minimum in light scattering between 2 and $4 \mathrm{~km}$ and a welldeveloped near-bottom nepheloid layer (C11-190 and V25-21, Figure 2). This kind of profile is observed in the western boundary undercurrent on the Caicos and Greater Antilles outer ridges and east of the Lesser Antilles.

The second class of profile is confined to the deeper water of the western Puerto Rico trench. It is characterized by low light scattering except for a midwater maximum that occurs near the depth of the Navidad sill and near the depth of the nearbottom nepheloid layer north of the sill (C10-14 and V24-156). This midwater maximum has scattering values from 0.5 to 0.8 $\log E / E_{i}$, representing suspended matter concentrations up to about $30 \mu \mathrm{g} / 1$ on the basis of in situ calibration of the nephelometer at $30^{\circ} \mathrm{N}, 74^{\circ} \mathrm{W}$ [Biscaye and Eittreim, 1974].

The third type of profile exhibits properties of both previous classes, having a midwater maximum near the sill depth as well as a near-bottom nepheloid layer (C16-28 and C16-30). These light scattering characteristics occur in the eastern Puerto Rico trench.

The relationship of these characteristics to the potential temperature structure of the water (in degrees centigrade, signified by $\theta$ ) in and around the trench is shown in Figure 3. The coldest water northwest of Navidad sill is about $1.56^{\circ} \theta$ [Tucholke et al.. 1973], and the near-bottom nepheloid layer associated with the western boundary undercurrent there is best developed in water up to about $1.9^{\circ} \theta$. The midwater 


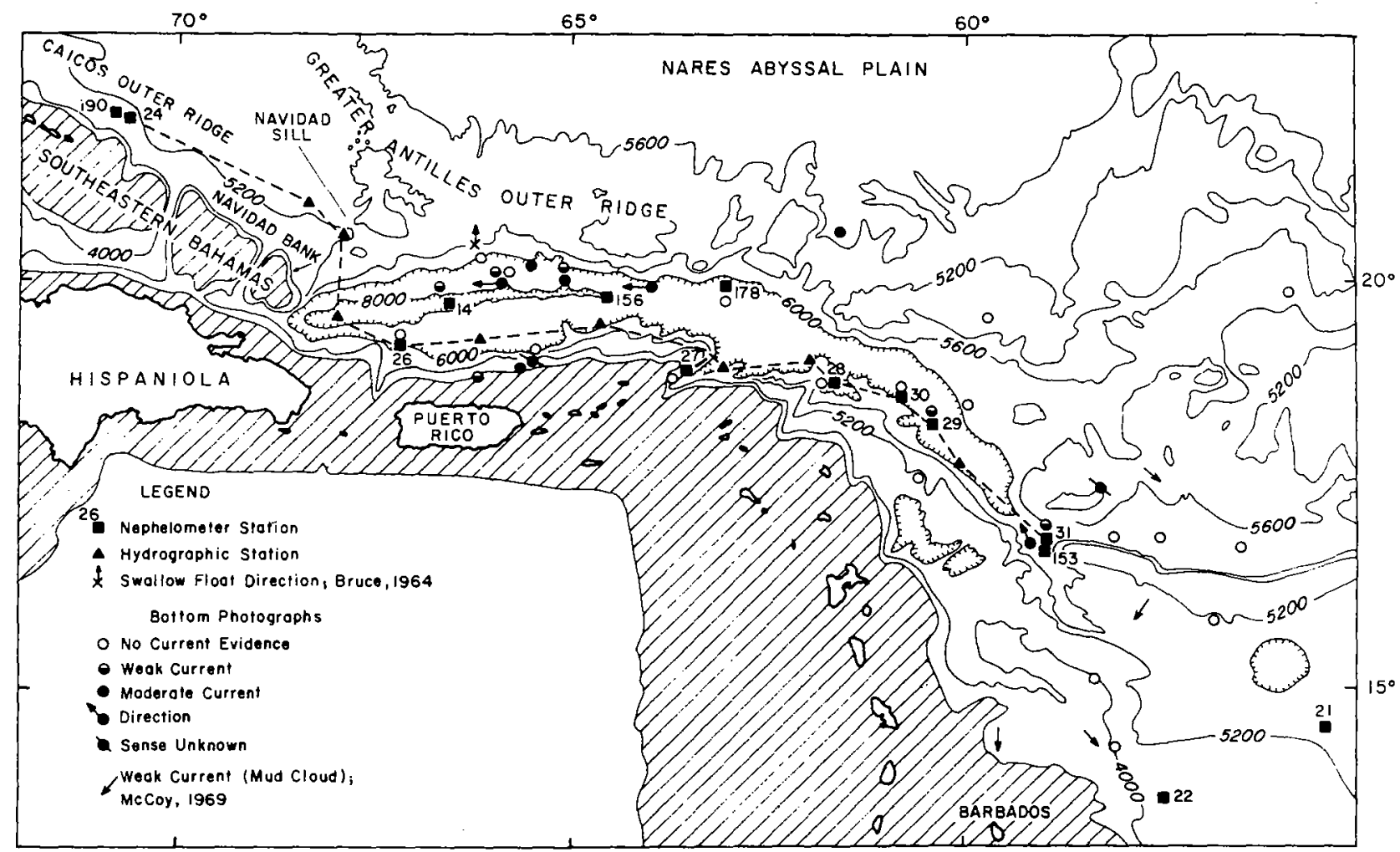

Fig. 1. Simplified bathymetry (in corrected meters) of the Puerto Rico trench and vicinity [Tucholke et al., 1973; E. Uchupi, unpublished manuscript, 1971] showing positions of nephelometer, hydrographic, and bottom photograph stations. Areas shallower than $3000 \mathrm{~m}$ are shaded. The dashed line gives the location of the potential temperature/turbidity section in Figure 3. Bottom photograph data are from the photograph libraries of Lamont-Doherty Geological Observatory and Woods Hole Oceanographic Institution.

nepheloid layer over the trench axis occurs in water of similar temperature $\left(1.5^{\circ}-1.8^{\circ} \theta\right)$, and it is separated from the sea floor by almost $3000 \mathrm{~m}$. The midwater maximum follows the isotherms and shoals to the east from a depth of about $5.4 \mathrm{~km}$ at $67^{\circ} \mathrm{W}$ to about $4.6 \mathrm{~km}$ at $59^{\circ} \mathrm{W}$. The isotherm pattern agrees with the potential temperature distribution in the trench determined by Worthington and Wright [1970].

The midwater maximum is less intense in our eastern profiles and is barely detected at station $\mathrm{C} 16-31$ at $59^{\circ} \mathrm{W}$. The lower boundary of the layer is sharply and consistently defined near the $1.5^{\circ} \theta$ isotherm, but the upper boundary is more gradual and deepens eastward, the result being a thin midwater maximum over the eastern trench.

The charts of Worthington and Wright [1970] show that antarctic bottom water colder than about $1.5^{\circ} \theta$ enters the Puerto Rico trench from the east (the antarctic bottom current). Much of the shallower part of this flow (down to about $1.47^{\circ}$ $\theta)$ probably has moderate velocity and may cross to the north through deep saddles in the Greater Antilles outer ridge [Tucholke et al., 1973]. However, water colder than this is confined within the trench and is probably characterized by sluggish flow. Whether this deep water escapes from the trench

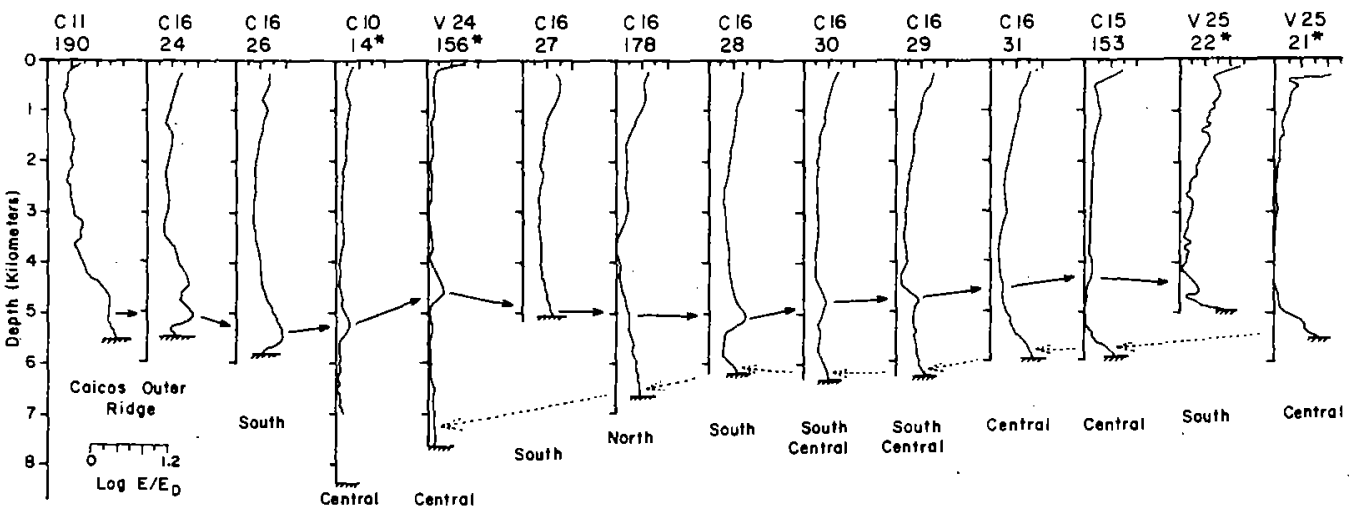

Fig. 2. Profiles of light scattering versus depth for all stations over the Caicos outer ridge, the Puerto Rico trench, and east of the Lesser Antilles. The relative position of each station with respect to the topographic axis of the trench is indicated, and positions are in Figure 1. Profiles with asterisks have no sensitometer control, and for these scattering is expressed in arbitrary units of film optical density (for other profiles of known optical density/film exposure retationships, optical density $\cong 1.3 \pm 0.2 \mathrm{film}$ exposure). Solid arrows trace the nepheloid layer associated with the easterly flowing western boundary undercurrent; dotted arrows show the layer in the deep portion of the westerly flowing antarctic bottom current. 


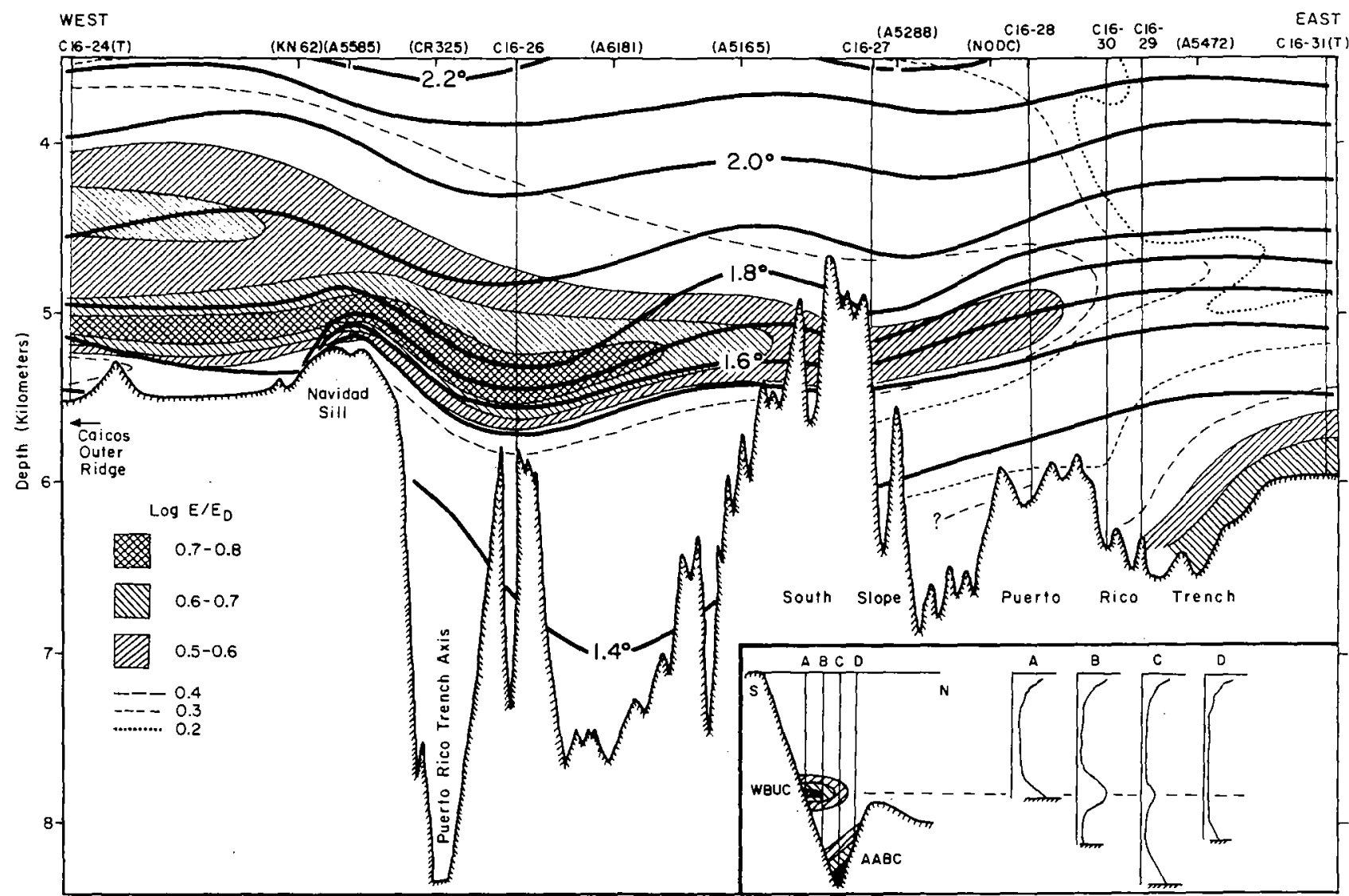

Fig. 3. Distribution of potential temperature and light scattering layers in a section from the Caicos outer ridge along the south slope of the Puerto Rico trench (see Figure 1 for location). Potential temperature data are derived from hydrographic stations (in parentheses) in the files of Woods Hole Oceanographic Institution and the National Oceanographic Data Center and from corehead $T$ grad measurements $(T)$. Units of light scattering are the log ratio of scattered to direct light in terms of film exposure $\left(E / E_{D}\right)$. Only nephelometer stations from Conrad cruise 16 that were taken over a period of 2 weeks and concentrated in the region south of the trench axis are shown. The insert at lower right is an idealized north-south cross section of the Puerto Rico trench showing the inferred nepheloid layers of the western boundary undercurrent and antarctic bottom current. Nephelometer stations at positions $A$ to $D$ would have the indicated light scattering profiles (compare with Figure 2). As is discussed in text, profiles A and D are class 1, profile B is class 2, and C is class 3.

by slow upward diffusion or by recirculation out along the south wall is uncertain. The near-bottom nepheloid layer in the eastern Puerto Rico trench is associated with water colder than about $1.4^{\circ} \theta$ in the antarctic bottom current, and it loses intensity to the west (Figures 2 and 3).

\section{DiscusSION}

We interpret the easterly extension of the midwater nepheloid layer as the continuation of the western boundary undercurrent over the Puerto Rico trench. Coriolis force should cause the current to bear against the south slope of the trench in its eastward flow; this observation is substantiated by the strong development of the midwater maximum near the south slope (Cl6-26 and Cl6-28, Figure 2) and its absence near the north slope (C16-178). The layer can be traced at least to station V25-22 east of the Lesser Antilles. Although the layer appears to weaken to the east, the weakening may be an artifact of the greater distance of nephelometer stations from the south slope in the eastern trench. The trench opens to a much broader profile in the east, and the current/nepheloid layer hugging the south slope at 4 to 5-km depth probably would be only weakly detected near the trench axis (Figure 3). On the other hand, we cannot rule out the possibility that the weakening is real. There are no nephelometer stations near the south slope of the eastern trench, and data from that area will be needed to ultimately resolve the problem.

The eastward thinning of the midwater scattering maximum and its absence in water colder than about $1.5^{\circ} \theta$ may be related to two factors. In the absence of strong turbulence generated by bottom friction, particles advected eastward by the western boundary undercurrent over the trench may settle, this settling causing the upper boundary of the layer to deepen. However, the lower boundary is maintained near $1.5^{\circ} \theta$ because particles that settle below this isotherm are removed by the clear shallow portion of the westerly flowing antarctic bottom current. The eastward thinning of the maximum suggests that the south slope of the trench is not important as a continuing source of particles for the western boundary undercurrent or as a source of turbulence generated by bottom friction. However, further stations near the south slope will be necessary to test this interpretation.

The near-bottom nepheloid layer in the eastern Puerto Rico trench is associated with water colder than $1.4^{\circ} \theta$ in the antarctic bottom current flowing into the trench (Figures 2 and 3 ). Because the trench creates a cul-de-sac for water that is this cold, the flow is probably sluggish and allows particle settling that weakens the nepheloid layer toward the west. There is little indication that the layer is better developed on the north 
side of the trench, as would be expected in a westerly flow.

Except for a single Swallow float measurement of a $2.1-\mathrm{cm} / \mathrm{s}$ current at $5500 \mathrm{~m}$ in antarctic bottom water on the north slope (J. G. Bruce, unpublished manuscript, 1964) the only direct determinations of deep current flow in the trench are from bottom photographs (Figure 1). Sediment microphysiography in the photographs suggests a weak to moderate flow $(<10 \mathrm{~cm} / \mathrm{s})$ of the antarctic bottom current along the north slope and similar weak currents, possibly associated with western boundary undercurrent, along the south slope. Weak southward flow $(<3 \mathrm{~cm} / \mathrm{s})$ of the western boundary undercurrent off the Lesser Antilles was suggested by $M c C u y$ [1969] from study of mud cloud dispersal, but these current determinations suffer the same severe limitations as short-term ( $<5 \mathrm{~min}$ ) current meter measurements. In any case, no strong currents capable of transporting large suspended sediment loads over great distances seem to be indicated in this region. Thus the available data on current intensities are compatible with weakening nepheloid layers downstream in both the western boundary undercurrent and the antarctic bottom current.

Acknowledgments. We thank P. E. Biscaye and A. L. Gordon for review of the manuscript. Marek Truchan served ably as chief scientist on Conrad cruise 16, and Marcus Langseth provided $T$ grad data. The nephelometer program at Lamont has been supported by the National Science Foundation under grant GA 41657 and GA 2728I and the Office of Naval Research under contract N00014-67-A-0108-0004. One of us (B.E.T.) was supported by a Lamont-Doherty PostDoctoral Fellowship during this research. Lamont-Doherty Geological Observatory contribution 2129 .

\section{REFERENCES}

Amos, A. F., A. L. Gordon, and E. D. Schneider, Water masses and circulation patterns in the region of the Blake-Bahama outer ridge, Deep Sea Res., 18, 145, 1971.

Biscaye, P. E., and S. Eittreim, Temporal variations in bottom boundary layer phenomena; Nepheloid layer, North American basin, in Suspended Solids in Water, edited by R. Gibbs, p. 227, Plenum, New York, 1974.

Eittreim, S., and M. Ewing, Suspended particulate matter in the deep waters of the North American basin, in Studies in Physical Oceanography, vol. 2, edited by A. L. Gordon, p. 123, Gordon and Breach, New York, 1972.

Eittreim, S., and M. Ewing, Turbidity distribution in the deep waters of the western Atlantic trough, in Suspended Solids in Water, edited by R. Gibbs, p. 213, Plenum, New York, 1974.

Eittreim, S., M. Ewing, and E. M. Thorndike, Suspended matter along the continental margin of the North American basin, Deep Sea Res. $16,613,1969$.

Ewing, M., and E. M. Thorndike, Suspended matter in deep ocean water, Science, 147, 1291, 1965.

Fuglister, F. C., Atlantic Ocean atlas of temperature and salinity profiles and data from the International Geophysical Year of 1957-1958, Woods Hole Oceanographic Institution Allas Series, vol. 1, p. 51, Woods Hole Oceanographic Institution, Woods Hole, Mass., 1960.

Heezen, B. C., C. D. Hollister, and W. F. Ruddiman, Shaping of the continental rise by deep geostrophic contour currents, Science, 152, $502,1966$.

McCoy, F. W.. Bottom currents in the western Atiantic Ocean between the Lesser Antilles and the mid-Atlantic ridge, Deep Sea Res., 16, 179, 1969

Swallow, J. C., and L. V. Worthington, An observation of a deep counter-current in the western North Atlantic, Deep Sea Res., 8, 1, 1961.

Thorndike, E. M., A deep-sea photographic nephelometer, Ocean Eng., in press, 1974

Thorndike, E. M., and M. Ewing, Photographic nephelometers for the deep sea, in Deep-Sea Photography, edited by J. B. Hersey, p. 113, Johns Hopkins Press, Baltimore, Md., 1967.

Tucholke, B. E., W. R. Wright, and C. D. Hollister, Abyssal circulation over the Greater Antilles Outer Ridge, Deep Sea Res., 20. 973, 1973.

Volkmann, G. H., Deep current observations in the western North Atlantic, Deep Sea Res., 9, 493, 1962.

Worthington, L. V., and W. R. Wright, North Atlantic Ocean atlas of potential temperature and salinity in the deep water including temperature, salinity and oxygen profiles from the Erika Dan cruise of 1962, Woods Hole Oceanographic Institution Atlas Series, vol. 2, pl. 10-18, Woods Hole Oceanographic Institution, Woods Hole, Mass., 1970.
(Received June 18, 1974; accepted June 29, 1974.) 